\title{
Implementasi Model EJAS Berbasis Mathematic Edutainment Untuk Meningkatkan Prestasi Belajar dan Perilaku Kepedulian Terhadap Lingkungan
}

\author{
Savitri Wanabuliandari ${ }^{1}$, Sekar Dwi Ardianti², Susilo Rahardjo ${ }^{3}$ \\ ${ }^{1}$ Universitas Muria Kudus, ${ }^{2}$ Universitas Muria Kudus, ${ }^{3}$ Universitas Muria Kudus \\ savitri.wanabuliandari@umk.ac.id ${ }^{1}$,sekar.dwi.ardianti@umk.ac.id ${ }^{2}$, susilo.rahardjo@umk.ac.id ${ }^{3}$
}

\begin{abstract}
Abstrak
Tujuan dari penelitian ini adalah (1) untuk mengetahui peningkatan prestasi belajar peserta didik melalui model EJAS berbasis mathematic edutainment dan (2) untuk mengetahui peningkatan perilaku kepedulian lingkungan pada peserta didik melalui model EJAS berbasis mathematic edutainment. Jenis penelitian yang digunakan adalah pre experimental design. Desain penelitian yang digunakan one group pre test-post test. Teknik pengambilan sampel menggunakan purposive sampling. Berdasarkan hasil analisis didapatkan (1) terjadi peningkatan prestasi belajar dengan tingkat peningkatan rendah sebesar 0\%, sedang 14,29\%, dan tinggi $85,71 \%$. Secara klasikal diperoleh nilai normalized gain $\langle g\rangle$ sebesar $90 \%$ atau 0,9 yang berarti tafsiran peningkatan prestasi belajar termasuk kategori tinggi (2) terjadi peningkatan terjadi peningkatan perilaku kepedulian terhadap lingkungan dengan skor peningkatan rendah sebesar 0\%, sedang sebesar 42,86\%, dan tinggi sebesar 57,14\%. Berdasarkan nilai normalized gain $\langle g\rangle$ secara klasikal diperoleh sebesar $73 \%$ atau 0,73 yang berarti tafsiran peningkatan perilaku kepedulian terhadap lingkungan yang terjadi termasuk kategori tinggi.
\end{abstract}

Kata kunci: EJAS, Mathematic Edutainment, Peduli Lingkungan, Prestasi Belajar

\begin{abstract}
The purposes of this study are (1) to find out the increase of learners learning achievement through EJAS model based mathematic edutainment and (2) to find out the increase of environmental concern behavior of learners through EJAS model based mathematic edutainment. The type of research used is pre experimental design. The design of research used is one group pretest-posttest. The sampling technique uses purposive sampling. Based on the analysis result, it is obtained (1) an increase of learning achievement of low level is $0 \%$, fair level is $14.29 \%$, and high level is $85.71 \%$. Classically it was obtained normalized gain value by $90 \%$ or 0.9 which means that the increase of learning achievement including high category (2) an increase of environmental concern behavior of low level increase is 0\%, fair level is 42,86\%, and high level is 57,14\%. Classically it was obtained normalized gain value by $73 \%$ or 0,73 which means that the increase of learning achievement including high category.
\end{abstract}

Keywords: EJAS, Mathematic edutainment, Environmental Care, Learning Achievement

\section{PENDAHULUAN}

Matematika sering dipandang sebagai mata pelajaran yang paling sulit. Banyak peserta didik yang merasa takut pada matematika, padahal matematika diberikan disemua jenjang pendidikan baik itu di pendidikan dasar maupun menengah. Menurut Puskur (2002) Matematika diberikan kepada peserta didik dengan tujuan agar peserta didik mampu menghadapi perubahan keadaan di dunia yang selalu berkembang. Puskur (2002) juga menyebutkan bahwa latihan yang dapat dilakukan agar dapat menghadapi perubahan dunia adalah dengan melatih diri untuk senantiasa bertindak secara logis, rasional, kritis, cermat, jujur dan efektif. Hal ini tidak dapat dicapai jika guru masih menerapkan metode hafalan serta hanya memberikan soal latihan yang bersifat rutin.

Kenyataannya, masih banyak peserta didik yang masih kesulitan dalam menyelesaikan masalah matematika. Kesulitan ini menyebabkan prestasi belajar matematika peserta didik masih rendah. beberapa faktor yang menyebabkan rendahnya prestasi belajar peserta didik adalah guru tidak 
menggunakan lingkungan sebagai sarana untuk belajar, peserta didik kurang aktif, merasa matematika sulit, dan peserta didik merasa bosan untuk belajar matematika. Hal ini terjadi karena karakteristik peserta didik di sekolah dasar yang cenderung masih suka bermain.

Untuk mengatasi permasalahan yang terjadi maka perlu diterapkan pembelajaran yang menyenangkan agar peserta didik dapat bermain sambil belajar sehingga peserta didik menjadi aktif, tidak takut dan tidak bosan dalam pembelajaran matematika. Salah satu cara agar pembelajaran matematika lebih menyenangkan adalah dengan menerapkan Mathematic edutainment. Mathematic edutainment sendiri merupakan pembelajaran matematika yang menggabungkan antara pendidikan dan hiburan, sehingga kegiatan pembelajaran yang dilakukan berlangsung dengan menyenangkan. Sutrisno (dalam hamid, 2011) berpendapat bahwa pembelajaran yang menyenangkan dapat dilakukan dengan humor, permainan, bermain peran dan demonstrasi.

Selain itu, Pembelajaran yang menyenangkan dapat dilakukan dengan cara lain asalkan peserta didik dapat menjalani pembelajaran dengan rasa senang. Dengan demikian pembelajaran berbasis Mathematic edutainment ini akan membantu peserta didik untuk belajar matematika dengan menyenangkan. Pembelajaran yang menyenangkan ini akan berdampak pada peningkatan prestasi belajar peserta didik dikarenakan (1) membuat peserta didik gembira dan pembelajaran terasa lebih mudah, (2) adanya komunikasi yang efektif dan penuh keakraban.

Berdasarkan hasil observasi awal yang telah dilakukan peneliti di SD 1 Bacin menunjukkan bahwa prestasi belajar peserta didik masih rendah. hal ini disebabkan karena peserta didik yang merasa bahwa matematika sulit dan membosankan sehingga menyebabkan peserta didik malas untuk mempelajarinya. Selain itu, perilaku kepedulian terhadap lingkungan masih rendah. Hal ini ditunjukkan dengan masih banyaknya peserta didik yang membuang sampah sembarangan, tidak merawat tanaman, dan peserta didik belum bisa diajak memanfaatkan kembali bahan yang tidak terpakai. Dalam pembelajaran di sekolah guru belum mengenal model pembelajaran yang dapat mengajak peserta didik untuk lebih peduli terhadap lingkungan.

Menurut Saptono (2011) perilaku peduli terhadap lingkungan dapat muncul, jika peserta didik selalu diajak untuk bertindak peduli terhadap lingkungan. Yuliati (2015) berpendapat dengan mengajarkan perilaku kepedulian terhadap lingkungan, peserta didik akan memahami bahwa segala kegiatan manusia yang mengarah pada pengrusakan akan memberikan dampak buruk terhadap manusia itu sendiri. Perilaku kepedulian terhadap lingkungan perlu ditanamkan karena sebagai upaya untuk mencegah terjadinya kerusakan lingkungan dan sebagai upaya untuk memperbaiki kerusakan yang sudah terjadi. Periaku kepedulian terhadap lingkungan dapat dilakukan dengan cara mengajak peserta didik untuk terjun langsung ke lingkungan.Dengan demikian, peserta didik akan selalu berperilaku peduli terhadap lingkungan.

Salah satu cara yang dapat dilakukan agar peserta didik tertanam perilaku kepedulian terhadap lingkungan adalah dengan menerapkan model pembelajaran yang dapat meningkatkan perilaku kepedulian terhadap lingkungan. Salah satu model yang dapat diterapkan adalah Experiential Jelajah Alam Sekitar (EJAS). Model pembelajaran ini mampu memberikan pengalaman yang efektif pada peserta didik. Peserta didik akan diberikan pengalaman tentang perilaku yang berkaitan tentang kepedulian terhadap lingkungan. Menurut Alimah (2012) model EJAS mampu memberikan pengalaman dalam pembelajaran sehingga akan mampu mengembangkan kemampuan personal, sosial, berpikir rasional, metakognisi dan kognisi pada peserta didik.

Melalui implementasi model EJAS berbasis Mathematic edutainment peserta didik diajak untuk belajar matematika secara 
menyenangkan dengan cara terjun berinteraksi dan terjun langsung ke lingkungan. Dengan penerapan model EJAS berbasis Mathematic edutainment diharapkan dapat meningkatkan prestasi belajarnya. Selain itu perilaku kepedulian terhadap lingkungan juga dapat meningkat.

Rumusan masalah yang akan diteliti dalam penelitian ini adalah sebagai berikut.

1. Apakah implementasi model EJAS berbasis mathematic edutainment dapat meningkatkan prestasi belajar peserta didik? dan

2. Apakah implementasi model EJAS berbasis mathematic edutainment dapat meningkatkan perilaku kepedulian terhadap lingkungan pada peserta didik?

Tujuan penelitian ini adalah sebagai berikut.

1. untuk mengetahui peningkatan prestasi belajar melalui implementasi model EJAS berbasis mathematic edutainment dan

2. untuk mengetahui peningkatan perilaku kepedulian terhadap lingkungan implementasi model EJAS berbasis mathematic edutainment.

Manfaat dalam penelitian ini adalah sebagai berikut.

1. Menambah referensi dibidang pendidikan, terutama dalam kajian karakter pada peserta didik,

2. menambah khasanah bacaan tentang peningkatan pretasi belajar dan perilaku kepedulian terhadap lingkungan melalui implementasi model pembelajaran EJAS berbasis mathematic edutainment, dan

3. sebagai bahan acuan dalam pelaksanaan pembelajaran di sekolah.

\section{KAJIAN PUSTAKA}

a. Model Experiential Jelajah Alam Sekitar (EJAS) berbasis Mathematic Edutainment

Model pembelajaran EJAS mampu memberikan pengalaman yang efektif pada peserta didik. Peserta didik akan diberikan pengalaman tentang perilaku yang berkaitan tentang kepedulian terhadap lingkungan. Menurut Alimah
(2012) model EJAS mampu memberikan pengalaman dalam pembelajaran sehingga akan mampu mengembangkan kemampuan personal, sosial, berpikir rasional, metakognisi dan kognisi pada peserta didik. Alimah (2014) menyebutkan bahwa model EJAS memberikan pengalaman langsung pada peserta didik untuk melakukan investigasi dengan cara eksplorasi cara eksplorasi dan berinteraksi langsung dengan obyek yang berada di lingkungan sekitar sebagai sumber belajar untuk mendapatkan pengetahuan, keterampilan,dan perilaku sebagai hasil belajarnya.

Menurut Alimah (2014) model EJAS ini memiliki 4 fase dalam pembelajaran yaitu sebagai berikut.

1. Eksplorasi yaitu mencakup kegiatan merancang dan mengembangkan ide dengan melakukan invetigasi di lingkungan,

2. interaksi yaitu kegiatan untuk mengembangkan kemampuan personal dan sosial melalui learning community

3. komunikasi yaitu kegiatan melatih dan membiasakan berkomunikasi dengan kata-kata yang santun dan empati

4. refleksi yaitu kegiatan melatih dan membiasakan kemampuan metakognisi.

Selain menggunakan model EJAS, peneliti juga menggunkan pendekatan Mathematic edutainment. Ade (2016) menjelaskan bahwa Edutainment berasal dari kata education dan entertainment. Education artinya pendidikan, sedangkan entertainment artinys hiburan. Jadi, dari segi bahasa, edutainment adalah pendidikan yang bertujuan untuk menghibur atau membuat pembelajaran menjadi menyenangkan. 
Menurut Shodiqin (2016) ada 4 point penciri pembelajaran edutainment yaitu sebagai berikut.

1. Jembatan penghubung antara proses mengajar dan proses belajar,

2. konsep dasar edutainment adalah bertujuan untuk menciptakan pembelajaran yang kondusif dan menyenangkan,

3. konsep edutainment memposisikan peserta didik sebagai pusat dari proses pembelajaran, sekaligus sebagai subjek pendidikan, dan

4. pembelajaran tidak lagi menakutkan, tetapi lebih humanis.

Mathematic edutainment sendiri merupakan pembelajaran matematika yang menggabungkan antara pendidikan dan hiburan, sehingga kegiatan pembelajaran yang dilakukan berlangsung dengan menyenangkan. Sutrisno (dalam hamid, 2011) berpendapat bahwa pembelajaran yang menyenangkan dapat dilakukan dengan humor, permainan, bermain peran dan demonstrasi. Jadi, model EJAS berbasis Mathematic edutainment berarti peserta didik diajak untuk belajar matematika secara menyenangkan dengan cara berinteraksi dan terjun langsung ke lingkungan.

\section{b. Perilaku Kepedulian Terhadap Lingkungan}

Menurut Saptono (2011) perilaku peduli terhadap lingkungan dapat muncul, jika peserta didik selalu diajak untuk bertindak peduli terhadap lingkungan. Yuliati (2015) berpendapat dengan mengajarkan perilaku kepedulian terhadap lingkungan, peserta didik akan memahami bahwa segala kegiatan manusia yang mengarah pada pengrusakan akan memberikan dampak buruk terhadap manusia itu sendiri.

Perilaku kepedulian terhadap lingkungan perlu ditanamkan karena sebagai upaya untuk mencegah terjadinya kerusakan lingkungan dan sebagai upaya untuk memperbaiki kerusakan yang sudah terjadi. Periaku kepedulian terhadap lingkungan dapat dilakukan dengan cara mengajak peserta didik untuk terjun langsung ke lingkungan. Dengan demikian, peserta didik akan selalu berperilaku peduli terhadap lingkungan.

\section{METODOLOGI}

a. Populasi dan Sampel

Populasi dalam penelitian ini adalah peserta didik di SD 1 Bacin, sedangkan subyek dari penelitian ini adalah peserta didik kelas IV di SD 1 Bacin. Dalam penelitian ini pengambilan sampel dilakukan dengan teknik purposive sampling. Variabel dalam penelitian ini adalah (1) variabel bebas yaitu model EJAS berbasis mathematic edutainment dan (2) variabel terikat yaitu prestasi belajar dan perilaku kepedulian terhadap lingkungan.

\section{b. Desain Penelitian}

Desain penelitian yang dilakukan dalam penelitian ini adalah one group pre test-post test. Ruseffendi (2010) menggambarkan desain tersebut adalah sebagai berikut.

\section{$\mathrm{O} \quad \mathrm{X} \quad \mathrm{O}$}

Keterangan:

$\mathrm{O}$ : Pretest dan posttest prestasi belajar dan perilaku kepedulian terhadap lingkungan.

$\mathrm{X}$ : Model EJAS berbasis mathematic edutainment

\section{c. Alur Pengolahan Data}

Metode pengumpulan data dengan dengan teknik tes dan nontes yang menggunakan lembar observasi. Instrumen yang digunakan dalam penelitian ini adalah lembar tes prestasi belajar dan lembar observasi perilaku kepedulian terhadap lingkungan. Teknik analisis yang dilakukukan adalah untuk menguji peningkatan prestasi belajar peserta didik dan perilaku kepedulian terhadap lingkungan pada peserta didik. Metode analisis data dalam penelitian ini dilakukan secara kuantitatif. Uji yang dilakukan untuk menguji peningkatan 
prestasi belajar dan perilaku kepedulian terhadap lingkungan adalah dengan menggunakan normalized gain.

\section{HASIL DAN PEMBAHASAN}

Penelitian dilakukan pada peserta didik kelas IV di SD 1 Bacin pada semester gasal tahun ajaran 2016/2017. Data hasil penelitian meliputi data skor prestasi belajar dan perilaku kepedulian terhadap lingkungan.

\section{Prestasi Belajar Peserta Didik}

Skor prestasi belajar peserta didik pada penelitian ini diperoleh dari pelaksanaan pretest dan posttest pada saat awal dan akhir penelitian, dengan menggunakan lembar tes prestasi belajar. Skor prestasi belajar sebelum dan sesudah penerapan model EJAS berbasis mathematic edutainment adalah seperti pada Tabel 1 berikut ini.

Tabel 1. Rekapitulasi Prestasi Belajar Sebelum dan Sesudah Pembelajaran.

\begin{tabular}{ccc}
\hline \multirow{2}{*}{ Komponen } & \multicolumn{2}{c}{ Skor Perilaku } \\
\cline { 2 - 3 } & Sebelum & Sesudah \\
\hline Rata-rata & 41,43 & 94,29 \\
Skor tertinggi & $0 \%$ & $85,71 \%$ \\
Skor terendah & $100 \%$ & $14,29 \%$ \\
\hline Per
\end{tabular}

Perolehan skor prestasi belajar sesudah pembelajaran secara umum lebih tinggi dibandingkan dengan skor sebelum pembelajaran. Hal tersebut dapat terlihat pada skor rata-rata prestasi belajar sesudah pembelajaran mencapai 94,29 dan sebelum pembelajaran mencapai 41,43. Skor tersebut selanjutnya dianalisis secara statistik dengan menggunakan uji normalized gain untuk mengetahui seberapa besar peningkatan skor prestasi belajar sebelum dan sesudah pembelajaran.

Hasil perhitungan untuk peningkatan prestasi belajar dengan menggunakan uji normalized gain dapat dilihat pada Tabel 2. berikut ini.
Tabel 2. Hasil Peningkatan Prestasi Belajar

\begin{tabular}{cc}
\hline Kriteria & Persentase \\
\hline Rendah & $0,00 \%$ \\
Sedang & $14,29 \%$ \\
Tinggi & $85,71 \%$ \\
\hline
\end{tabular}

Berdasarkan Tabel 2. dapat diketahui bahwa hasil peningkatan prestasi belajar dengan tingkat peningkatan rendah sebesar $0 \%$, sedang sebesar $14,29 \%$, dan tinggi sebesar 85,71\%. Secara klasikal diperoleh nilai normalized gain $\langle g\rangle$ sebesar $90 \%$ atau 0,9 yang berarti tafsiran peningkatan prestasi belajar termasuk kategori tinggi.

\section{Perilaku kepedulian terhadap} lingkungan

Perilaku kepedulian terhadap lingkungan merupakan perilaku yang selalu berupaya untuk mencegah kerusakan lingkungan alam di sekitarnya dan berupaya untuk membantu memperbaiki kerusakan alam yang sudah terjadi. Indikator yang yang digunakan dalam observasi karakter peduli lingkungan peserta didik adalah keinginan peserta didik untuk berpartisipasi dalam membersihkan lingkungan sekolah mengambil sampah yang berserakan, tidak merusak lingkungan sekolah, memisahkan sampah organik dan anorganik, memberikan ide pemanfaatan sampah dalam diskusi kelompok, memanfaatkan/ mengubah barang bekas dan bahan alam, membuang sampah pada tempatnya, dan mengingatkan sesama untuk membuang sampah pada tempatnya.

Skor perilaku kepedulian terhadap lingkungan pada penelitian ini diperoleh dari kegiatan observasi selama proses pembelajaran dengan menggunakan lembar observasi. Skor perilaku kepedulian terhadap lingkungan sebelum dan sesudah penerapan model EJAS berbasis mathematic edutainment seperti pada Tabel 3 berikut ini. 
Tabel 3. Rekapitulasi Skor Perilaku

Kepedulian Terhadap Lingkungan

Sebelum dan Sesudah Pembelajaran.

\begin{tabular}{ccc}
\hline \multirow{2}{*}{ Komponen } & \multicolumn{2}{c}{ Skor Perilaku } \\
\cline { 2 - 3 } & Sebelum & Sesudah \\
\hline Rata-rata & 2,71 & 6,57 \\
Skor tertinggi & 4 & 7 \\
Skor terendah & 2 & 6 \\
\hline
\end{tabular}

Perolehan skor perilaku kepedulian terhadap lingkungan sesudah pembelajaran secara umum lebih tinggi dibandingkan dengan skor sebelum pembelajaran. Hal tersebut dapat terlihat pada skor rata-rata perilaku kepedulian terhadap lingkungan sesudah pembelajaran mencapai 6,57 dan sebelum pembelajaran mencapai 2,71. Skor tersebut selanjutnya dianalisis secara statistik dengan menggunakan uji normalized gain untuk mengetahui seberapa besar peningkatan skor perilaku kepedulian terhadap lingkungan sebelum dan sesudah pembelajaran.

Hasil perhitungan untuk peningkatan perilaku kepedulian terhadap lingkungan dengan menggunakan uji normalized gain dapat dilihat pada Tabel 4 . berikut ini.

Tabel 4. Hasil Peningkatan Perilaku Kepedulian Terhadap Lingkungan

\begin{tabular}{cc}
\hline Kriteria & Persentase \\
\hline Rendah & $0,00 \%$ \\
Sedang & $42,86 \%$ \\
Tinggi & $57,14 \%$ \\
\hline
\end{tabular}

Berdasarkan Tabel 4. dapat diketahui bahwa hasil peningkatan perilaku kepedulian terhadap lingkungan dengan tingkat peningkatan rendah sebesar $0 \%$, sedang sebesar $42,86 \%$, dan tinggi sebesar 57,14 \%. Berdasarkan nilai normalized gain $\langle g\rangle$ secara klasikal diperoleh sebesar $73 \%$ atau 0,73 yang berarti tafsiran peningkatan perilaku kepedulian terhadap lingkungan pada kategori tinggi.

Rata-rata skor perilaku kepedulian terhadap lingkungan sesudah dilakukan pembelajaran model EJAS berbasis mathematic edutainment lebih tinggi dari sebelum pembelajaran. Dari hasil uji normalized gain menunjukkan bahwa sebanyak $57,14 \%$ dari peserta didik mengalami peningkatan skor perilaku kepedulian terhadap lingkungan. Pada skor menunjukkan bahwa peningkatan perilaku kepedulian terhadap lingkungan pada kategori tinggi. Peningkatan skor perilaku kepedulian terhadap lingkungan pada peserta didik sesudah pembelajaran disebabkan karena penerapan model EJAS berbasis mathematic edutainment. Alimah (2014) dalam penelitiannya menyatakan bahwa model EJAS akan memberikan pengalaman kepada peserta didik terkait dengan kemampuannya untuk menggali dan menemukan informasi, mengolah informasi, mengambil keputusan, serta untuk memecahkan masalah. Hal ini senada dengan hasil penelitian dari Aulia (2016) bahwa model EJAS memberikan respon positif terhadap peserta didik.

Kegiatan yang dilakukan pada saat implementasi model EJAS adalah (1) eksplorasi yaitu peserta didik diajak untuk merancang, mengembangkan ide dan pengalaman melalui kegiatan investigasi terhadap permasalahan yang ada di lingkungan sebagai objek belajar peserta didik, (2) interaksi yaitu peserta didik diajak untuk mengembangkan kemampuan personal dan sosial melalui kegiatan belajar kelompok (3) komunikasi yaitu kegiatan membiasakan peserta didik untuk berkomunikasi dengan bahasa yang santun melalui kegiatan diskusi dan presentasi, dan (4) refleksi merupakan kegiatan melatih, mengembangkan, dan membiasakan kemampuan metakognisi peserta didik melalui kegiatan membuat kesimpulan baik tentang konsep yang diterima maupun tentang pengalamannya pada saat pembelajaran.

Pembelajaran EJAS mengajak peserta didik untuk melakukan kegiatan investigasi melalui jelajah alam sekitar sehingga peserta didik dapat mengetahui secara langsung kondisi nyata di lingkungannya. Pembelajaran secara langsung di lingkungan 
ini dapat memberikan pengetahuan dan pengalaman bagi peserta didik, sehingga peserta didik mampu menentukan perilaku yang baik terhadap lingkungan. Selain menggunakan model pembelajaran EJAS, peneliti juga menggunakan pendekatan mathematic edutainment. Menurut Ade (2016) penggunaan pendekatan edutainment pada pembelajaran matematika memberikan respon positif. Respon positif tersebut ditunjukkan dengan adanya peningkatan prestasi belajar pada peserta didik. Ade (2016) juga menjelaskan bahwa pembelajaran berbasis edutainment membuat pembelajaran matematika lebih menyenangkan, menarik, mudah dimengerti, dan jelas sehingga menyebabkan prestasi belajar peserta didik meningkat.

Penerapan Model EJAS berbasis mathematic edutainment memberikan pengalaman belajar matematika yang menyenangkan, dilakukan secara langsung melalui kegiatan investigasi yang berupa eksplorasi dan interaksi secara langsung dengan obyek belajar yang ada di lingkungan peserta didik sebagai sumber belajar. Model EJAS berbasis mathematic edutainment membuat pembelajaran matematika lebih menyenangkan dan menarik, sehingga memberikan dampak terhadap peningkatan skor prestasi belajar. Selain itu, dalam pembelajaran ini juga dapat meningkatkan skor perilaku kepedulian terhadap lingkungan pada peserta didik baik secara invidual maupun secara klasikal. Peserta didik juga memberikan respon yang baik terhadap lingkungannya, hal ini ditunjukkan dengan adanya peningkatan pada skor perilaku kepedulian terhadap lingkungan.

\section{KESIMPULAN DAN SARAN}

\section{a. Kesimpulan}

Berdasarkan hasil penelitian yang telah di lakukan di SD 1 Bacin Kelas IV tahun pelajaran 2016/2017 dan pembahasan pada tema peduli terhadap makhluk hidup maka dapat disimpulkan bahwa model EJAS berbasis mathematic edutainment dapat meningkatkan prestasi belajar dan perilaku kepedulian terhadap lingkungan dikarenakan (1) terjadi peningkatan prestasi belajar dengan tingkat peningkatan rendah sebesar $0 \%$, sedang sebesar $14,29 \%$, dan tinggi sebesar 85,71 $\%$. Secara klasikal diperoleh nilai normalized gain $\langle g\rangle$ sebesar $90 \%$ atau 0,9 yang berarti tafsiran peningkatan prestasi belajar termasuk kategori tinggi (2) terjadi peningkatan terjadi peningkatan perilaku kepedulian terhadap lingkungan dengan skor peningkatan rendah sebesar $0 \%$, sedang sebesar $42,86 \%$, dan tinggi sebesar $57,14 \%$. Berdasarkan nilai normalized gain $\langle g\rangle$ secara klasikal diperoleh sebesar $73 \%$ atau 0,73 yang berarti tafsiran peningkatan karakter peduli lingkungan yang terjadi pada kategori tinggi.

b. Saran

Dari hasil penelitian yang telah dilakukan, peneliti dapat memberikan saran yaitu sebagai berikut.

1. Guru dalam menyampaikan materi dapat menerapkan model EJAS berbasis mathematic edutainment sebagai alternatif untuk meningkatkanprestasi belajar serta perilaku kepedulian terhadap,

2. Dalam proses pembelajaran memerlukan adanya variasi pembelajaran sehingga peserta didik menjadi tertarik dan aktif dalam mengikuti pembelajaran,

3. Guru dapat berinisiatif dan kreatif dalam mendayagunakan lingkungan sekitar dalam pembelajaran sehingga peserta didik lebih mudah mempelajari dan memahami materi yang diberikan,

4. Dalam penerapan pembelajaran model EJAS berbasis mathematic edutainment perlu adanya pengawasan terhadap peserta didik, sehingga pembelajaran dapat berjalan secara efektif.

\section{DAFTAR PUSTAKA}

Ade Saepudin, Saluky Saluky, \& Muhammad Ali Misri. (2016). The Use Effects Of Interactive Multimedia Edutainment On The Achievement Improvements In Mathematics. Information Technology Engineering Journals, 1 (1), 1-15.

Alimah, S. (2012). Pengembangan Pembelajaran Experiential Jelajah Alam Sekitar pada Mata Kuliah Biologi. 
Proceeding Seminar Nasional MIPA

Unnes. Semarang: Universitas Negeri Semarang.

Alimah, S. (2014). Model Pembelajaran Eksperiensial Jelajah Alam Sekitar. Strategi untuk meningkatkan kemampuan berpikir kritis mahasiswa. Jurnal Penelitian Pendidikan, 3 (1), 47 54.

Aulia Zulfatu Nisa, Siti Alimah, Aditya Marianti. 2016. Pengaruh Penerapan Desain Pembelajaran Animalia dengan Model Eksperiensial Jelajah Alam Sekitar di SMA. Lembaran Ilmu pendidikan, 45 (1), 20-27.

Hamid, Sholeh. (2011). Metode Edutainment. Yogyakarta: Diva Press

Puskur. (2002). Kurikulum dan Hasil belajar Kompetensi Dasar Mata pelajaran Matematika dan Madrasah. Jakarta: Balitbang Depdiknas

Ruseffendi, E. T. (2010). Dasar-dasar penelitian pendidikan \&bidang noneksakta lainnya. Bandung: Tarsito

Saptono. (2011). Dimensi-dimensi Pendidikan Karakter, Wawasan, Strategi, dan Lengah Praktis. Salatiga: Erlangga

Shodiqin, Rahmat. (2016). Pembelajaran Berbasis Edutainment. Jurnal AlMaqoyis, 4 (1), 36-52

Tika Yuliati \& Nana Kariada Tri Martuti. (2015). Efektifitas Penerapan Model Field Trip Untuk Meningkatkan Hasil Belajar dan Kepedulian Siswa Terhadap Lingkungan. Jurnal Pendidikan Matematika dan Sains, 3 (1), 39-48. 